\title{
Determinants of Private Investment Contracts in the Basic Sanitation Sector: Evidence for Developing Countries
}

Dianifer Leal Borges ( $\sim$ dianiferleal@hotmail.com )

Universidade Federal de Pelotas https://orcid.org/0000-0002-0004-5036

Rodrigo Nobre Fernandez

Universidade Federal de Pelotas

Cláudio Djissey Shikida

Universidade Federal de Pelotas

Luciana de Andrade Costa

Universidade do Vale do Rio dos Sinos

Research

Keywords: Private investment, Infrastructure, Basic Sanitation

Posted Date: June 2nd, 2020

DOI: https://doi.org/10.21203/rs.3.rs-31377/v1

License: (c) (i) This work is licensed under a Creative Commons Attribution 4.0 International License.

Read Full License 


\section{Abstract}

Investment in infrastructure is a key factor for improving the quality of life of the population and, consequently, for the economic development of nations. In this context, the universalization of water and sanitation services is of great importance due mainly to their impact on public health. Based on the work of Yehoue et al. (2006) and Sharma (2012), this article studies the determinants of the number of private investment contracts for the basic sanitation sector. In the empirical analysis, with a panel of developing countries during the years 2003-2016, we use the following counting estimators to study the number of contracts in the sector: Negative, Poisson, Negative Binomial, and Zero Inflated negative binomial with corrected Vuong (ZINBCV). The results show that the channels of the macroeconomic environment, foreign investment and the political environment are the main determinants in the formulation of new contracts in the basic sanitation sector.

\section{Introduction}

The responsibility for the provision of infrastructure services, to meet population's demand, is of the government authorities. Since the late 1980s, many developing countries have allowed the private sector to invest in infrastructure, seeking an alternative solution to budget deficits, and hoping to foster investment and economic growth (TRUJILLO et al., 2002). According to the World Bank, the investment in water and sanitation in developed countries between the years 1990 and 2016 was of $\$ 80.901$ billion dollars in a total of 996 infrastructure projects.

The investment in infrastructure is an essential factor for the improvement of the population's life quality. Basic sanitation is an essential sector for the well-being of individuals, in which the failure of services provision, along with inadequate access to drinking water and sewage treatment, directly interferes with public health, negatively influencing the sustainable development of countries and creating a favorable environment for diseases due to precarious conditions.

The universalization of water and sanitation services is of great importance due mainly to their impact on public health. According to a World Health Organization's (WHO) report of 2014, for every dollar invested in water and sanitation, US\$ 4.3 in health care costs are saved worldwide. Given that, adequate provision of water and sanitation services may reduce the need for an increase in health care spending related to illnesses caused by the lack of adequate access to those services, which is more common in developing countries.

In this scenario, due to the high initial investment needed in infrastructure, the participation of private investors has been stimulated by governmental organizations in alternative managerial arrangements in order to finance infrastructure investment projects and to reach a higher level of well-being. In the context of contract models, privatizations and concessions, such as public-private partnerships, are some alternatives adopted by governments to fill the gap between fiscal restraint and demand for infrastructure to manage. Unlike privatization, in which the asset is sold to the private agent and, consequently, the 
asset's ownership changes, the concession contracts, although they generally have different rules among countries, have as main characteristic a long-term contractual modality, aiming to leverage infrastructure investments.

In this context, empirical studies such as: Chong et al. (2006); Yehoue et al. (2006); Wang et al. (2011); Sharma (2012); Fernandez et al. (2015); and Pusok (2016); have advanced in the understanding of these contractual relations. Thus, the theoretical and empirical study of these contractual modalities is an important factor for public policy makers, helping as a fundamental instrument for contractual design, taking into account possible contingencies that could lead to contract failure. In addition, contracts are generally classified as incomplete and long-term failures may be unpredictable.

Following Yehoue et al. (2006) and Sharma (2012), this article aims to identify the determinants of the number of contracts for the water and sanitation sectors in developing countries. We use a panel for developing countries from 2003 to 2016. Our database focuses on global development indicators, governance indicators and private participation in infrastructure investments (Private Participation Infrastructure Data Base - PPI), provided by the World Bank.

This study contributes to the literature by analyzing the basic sanitation sector for developing countries, seeking to investigate the determinants of the number of contracts (dependent variable) in this sector. Using panel data count estimators, we propose a new variable to control for the excessive number of zeros, since when the country does not have the contract information in a given year, it assumes the value of zero, which can be explained by long-term concession contracts and the fact that a contract might be in place at that moment.

Thus, based on the instrument proposed by Acemoglu et al. (2014), which considers the spillover effects of democracy in neighboring countries, our variable is based on the premise that the concessionary practices of countries of the same region, that is, that share borders, can generate spillover effects on neighboring countries, reducing likelihood of not having contracts and inducing them to adhere to contractual arrangements.

Unlike the literature, the empirical part of the paper uses the Zero Inflated Negative Binomial (ZINB) model, with the Vuong correction by AIC (Akaike) and BIC (Schwarz) with regional, income and temporal effects, to solve possible problems caused by counting regressions with an excessive number of zeros. In addition, variables related to foreign investment are used and the estimates generated by Poisson and Negative Binomial models with random effect are presented for analysis robustness purposes.

In short, the results found in the estimates indicate that the channels of a stable macroeconomic environment coupled with foreign investment and the political stability of nations are preponderant for the attractiveness of private investors to the increase in the number of contracts in the sector. In addition, our control variable for the excessive number of zeros has a strong overflow effect on all estimated models, which reduces the likelihood of neighboring countries not having contracts in the water and sanitation sector. That is, the fact that border countries have concession contracts reduces the probability 
of Brazil, for example, in approximately $70 \%$ when we estimate with an income dummy, that the country does not have contracts in the sector.

Following this introduction, in section two, we present the literature review that discusses the importance of the basic sanitation sector and the possible determinants of private investment. In section three, we present the hypotheses to be tested and the channels for specification of the empirical models. In section four, the data and the empirical strategy used are described. In section five the results are described and discussed. Finally, in the last section, are the final considerations.

\section{Literature Revision}

There is a vast literature on the determinants of private investments in infrastructure, such as the works of Hart et al. (1997); Hart, (2003); Harris, (2003); Bennet and lossa, (2006); Engel et al., (2009); lossa and Martimort, (2012); lossa and Saussier, (2018). However, there are few empirical studies we are aware of that quantify the efficiency and the determinants of infrastructure investment in the use of concession contracts at an aggregate level for developing countries regarding the provision of water and sanitation services.

The provision of basic services, such as education, health, security and infrastructure, are the responsibility of government authorities. Basic sanitation is essential for the well-being of the population, where the lack of this provision with inadequate access to drinking water and sewage treatment directly affects public health, negatively influencing economic development and creating a favorable environment for diseases due to poor conditions. In line of this, a massive investment that fills this serious gap between provision and adequate access may significantly reduce diseases related to lack of sanitation and, especially, infant mortality (FUJIWARA, 2005).

According to the World Health Organization's (WHO) report of 2014, for every dollar invested in water and sanitation, US\$ 4.3 in health costs are saved worldwide. In this way, adequate provision of services in this sector may reduce the need for increased health care spending related to illnesses stemming from the lack of adequate access to services, which is quite common in developing countries.

In this context, the universalization of water and sanitation services is of great importance for sustainable development. According to the United Nations, developing countries have until 2030 to meet the targets set by the Sustainable Development Goals (ODS) agenda. Among the goals is the ODS6 for water and sanitation sector, with the objective of ensuring adequate access to safe water and sanitation for all and increasing the efficiency of the use of treated water in all sectors. Thus, infrastructure investments need to have a substantial increase in these economies in order to support economic growth and meet environmental goals related to preservation (IOSSA and SAUSSIER, 2018).

The resources collected by governments through taxes should be transferred largely to meet the demands for basic services. However, it is important to note that in developing countries, on average, financial resources for infrastructure investments are scarce. High growth rates may attract more investors, 
increasing demand for infrastructure and thus promoting partnerships among private companies (RESIDE, 2009). According to Acemoglu and Robinson (2010), differences in economic growth rates may have as a factor the heterogeneity of the institutions of each country. That is, the difference in growth among nations may be due to institutional problems .

Since the late 1980s, many developing countries have allowed private sector investment in infrastructure sectors, in order to reduce budget deficits, and expecting to foster investment and economic growth (TRUJILLO et al., 2002). To eliminate infrastructure deficiencies and achieve a higher level of well-being, the participation of private investors in alternative organizational arrangements has been stimulated by governmental organizations in order to finance investment projects in infrastructure.

In this sense, the entry of the private sector may help the end of this vicious circle, since it tackles its main aspects such as low tariffs, management inefficiency, obsolete business practices and the mix up between politics and the internal management of firms (FERREIRA, 2007). Thus, fiscal restraint serves as a lever for the emergence of new arrangements of public services contracts and a transfer of responsibility to private partners (GUASCH, 2004).

As Sharma (2012) points out privatization is not adequate in infrastructure projects due to the complexity of management and intensive capital. According to Yehoue et al. (2006), mutually beneficial partnerships between the public and private sectors may be important and private companies cannot have the responsibility for building and/or providing public infrastructures independently. In line with this view, we emphasize that public interest does not necessarily have to be attended only by public companies. In administrative terms, the responsibility for providing the services is public, but the management may be public or private. In these cases, the local authority remains partially responsible for the provision of services, while the private agent is in charge of the infrastructure and maintenance of the public good.

It should be noted that, for the purpose of this study, the main difference between public and private management lies in the incentives to which each one submits. Under private management, incentives can lead to cost minimization and, consequently, to the improvement of the quality of the services offered. On the other hand, in the public sector, incentives can be linked to political interests, stimulating rent-seeking, and promoting the redistribution of resources from society to these groups through the use of the political system.

In the meantime, it should be noted that incentives for corruption gains may occur in both public and private sectors. The difference is that the private agent has more incentive to seek profits, in some contractual arrangements, they take all risk. Thus, incentives in the private sector may reduce costs and improved service quality. It should be emphasized the importance of property rights, since residual control rights determine who has the authority to approve changes in the process or innovations related to the asset (HART, 2003; IOSSA and MARTIMONT, 2012).

In the context of contractual models, privatizations, and concessions, such as public-private partnerships, are some alternatives to bridge the gap between fiscal restraint and demand for infrastructure, according 
to the institutional constraints of each country, to manage activities previously provided by the public agent. It is recurrent to the association of concession contracts and public-private partnerships with privatization. Given this, it is important to highlight the differences between these contracts.

In the first place, the concession delegates the execution of the public service to a private agent, without giving ownership of the property, contrary to privatization. In the second place, public-private partnerships (PPPs) are a type of concession contract, but they have different rules from those of common concession law regarding how the private agent's remuneration.

In general, PPP laws take different forms among countries, but usually this contractual model has a longterm. Finally, privatization refers to the sale of public assets to private enterprises, resulting in the control of private company over the property (e.g.: administration, investment and provision).

In this context, private sector participation may present an alternative solution for infrastructure financing, substituting the provision of fully public and private services, inducing the minimization of production costs by the private provider and of possible market failures that could occur under full privatization (CHONG et al., 2006). In this sense, in the traditional concession contracts all the risk lies with the private sector. PPPs, on the other hand, have an advantage where public and private sectors share the investment's risks given the high initial investment required and the uncertain long-term return. This contractual model allows to pool risks and to limit the liability of only one of the contracting parties, also sharing the benefits (NISAR, 2007).

As for the empirical evidence, Chong et al. (2006) estimates the impact of organizational choice on performance in the sanitation sector measured by consumer prices, controlling for supply and demand aspects that may affect prices. The authors find evidence that consumers pay more when municipalities choose PPPs. Wang et al. (2011) analyze the impact of the private sector on water supply in China and find evidence that private sector participation significantly improves water supply capacity, and that private international firms improve sector performance more than local private companies do.

Within this context, Yehoue et al. (2006) highlight the importance of governance and political stability issues on private investment in infrastructure. The authors investigate the determinants of public-private partnerships in emerging economies from 1990 to 2003, using a Zero Inflated Poisson (ZIP) model for the number of infrastructure projects for sectors such as energy, sanitation, transport and telecommunications. The study uses proxies aiming to investigate possible channels for budget constraint, market size, political environment, economic environment, and institutional quality. The results indicate that private investment prevails in economies with relatively large markets, high budget deficits and a stable political environment.

In the same line, Sharma (2012) studies the determinants of PPPs in developing countries from 1990 to 2008. Using a ZIP model, results show that macroeconomic stability, regulatory and governance quality and also market size are important for the private sector to engage in infrastructure projects. 
Similarly, the study by Fernandez et al. (2015) sought to identify the determinants of investment and the number of public-private partnerships (PPPs) for developing countries in four sectors: water and sanitation, energy, telecommunications and transportation. Specifically for the water and sanitation sector, the important channels to determine the contracts were the political and legal systems, and macroeconomic environment. In a recent study, Pusok (2016) investigates how foreign private investment through public-private partnerships affects access to water and sanitation in developing countries. The results demonstrate the negative effects of corruption on the efficiency of private investments, given that when corruption is high in a country, private investors seek to maximize profit regardless of the demand for sanitation, which leads them to provide better quality water, but not adequate sanitation.

The studies of Prasad (2006), Frone (2013), Jiang et al. (2015) and Zeneli (2017) find evidence that private sector participation may have positive effects on infrastructure projects. In short, the literature provides evidence that private sector participation may be a good alternative in infrastructure investment improvements for developing countries, bringing innovation and technology to the water and sanitation sector. In the next section, we present the hypotheses of our study, in order to investigate the determinants of the numbers of contracts in the sanitation sector.

\section{Empirical Hypotheses}

In this section, we present the hypotheses that serve as the basis for our empirical model, in order to test which channels determine the number of contracts in the basic sanitation sector for developing countries. Addressing the issue of foreign investment, according to Wang et al. (2011), private international companies improve the performance of infrastructure investment relative to local companies, and most of the infrastructure projects are financed with foreign capital. Yehoue et al. (2006) argue that private investments tend to be more common in countries where governments suffer from heavy debt burdens. On the other hand, high external debt may mean that the country has a greater ability to raise external resources (such as the IMF), mitigating possible fiscal shocks, and there is no need to stablish partnerships with the private sector for investments. Thus, we use two variables as proxies for foreign investment: (i) multilateral debt as a percentage of total external debt stock, loans and credits from the World Bank, regional development banks and other multilateral and intergovernmental agencies; and (ii) foreign direct investment as a percentage of Gross Domestic Product (GDP). Based on these arguments we present the first hypothesis:

Hypothesis 1: Foreign capital investments affect the number of projects in infrastructure.

A second important point is the demand for infrastructure in countries with fiscal restraint. Access to infrastructure services continues to be limited to a large share of the world's poorest populations (ESTACHE, 2006). Given this, we consider that countries with budget deficits and a larger population demand more infrastructure services and are more likely to collaborate with the private sector to fill gaps between supply and demand of public services. Therefore, we use population growth as a proxy for infrastructure demand. With this, we try to investigate the following hypothesis: 
Hypothesis 2: Developing countries that are more populous demand more infrastructure services, which encourages the formation of partnerships with the private sector.

As for the country's macroeconomic environment, the degree of macroeconomic stability is important, because it could be used as an indicator which helps contracting parties to predict possible project contingencies (IOSSA and SAUSSIER, 2018). In general, infrastructure projects have high initial costs and the return on investment is of long term (YEHOUE et al., 2006). Thus, we use an indicator to test private attractiveness, being it the domestic credit to the private sector as a proportion of GDP. Considering these arguments, we intend to test the following hypothesis:

Hypothesis 3: Private investments in infrastructure are more likely in countries with a stable macroeconomic environment.

In addition to the macroeconomic environment, another aspect related to private investment is the business environment. In general, institutional quality such as corruption control and political stability are important factors for attracting private investment in developing countries, facilitating the business environment with the private sector (RESIDE, 2009). Compliance with contracts is another important factor for a country's credibility in attracting private companies. Legal institutions have a significant effect on private investment (PISTOR et al., 2000). Therefore, we test the conditions of the business environment including the degree of economic openness of the country. In this context, our hypothesis is as follows:

Hypotheses 4: A good business environment encourages private companies to get involved in infrastructure projects.

Weak political institutions increase the risk of corruption, reducing contract performance (IOSSA and SAUSSIER, 2018). Investments depend on political stability, centered on laws and regulations (JIANG, 2015). In this way, political instability and corruption affect the attractiveness and success of contracts with private companies, especially foreign ones. The country's high risk discourages investors from engaging in private partnerships (PISTOR et al., 2000). On the other hand, political instability may serve as an incentive for private investors seeking gains through corruption. In order to measure the effect of public sector governance, we use the World Bank's perception of corruption index. We should emphasize that this index does not measure corruption, but it identifies how this fact is perceived in each country, where it captures the perception of how public power is exercised for improper gains. This index ranges from -2.5 to 2.5 , where the higher the less corrupt the country is. Therefore, we formulate the following hypothesis:

Hypothesis 5: Politically stable economies are more likely to attract investment through private capital.

In sum, the hypotheses are divided into five channels, taking into account the restrictions and incentives of public and private agents: foreign investment, demand for infrastructure, macroeconomic environment, 
business environment, and political environment. In the next section, we present the methodology used to test the five hypotheses.

\section{Methodology}

In this section, we present the data and our empirical strategy.

\subsection{Data}

We use data from the World Bank on private participation in infrastructure investments (PPI) for developing countries in the water and sewage sector. The PPI database provides information on the number of contracts for each of those investments from 2003 to 2016. Also, developing countries are classified as low and middle income based on per capita income and ability to borrow in market terms.

In this study, we analyze the determinants of the number of contracts in infrastructure, focusing on the basic sanitation sector, which consists of water distribution, sewage treatment and public cleaning. In addition to the PPI database, we use data on global development and governance indicators from the World Bank database.

The dependent variable (project number) was constructed from contract aggregation for each country each year in the specific water and sanitation sector according to the information made available on the PPI website. However, this variable has a high number of zeros, which occur for mainly two potential causes: (i) lack of demand for concession projects; (ii) the time of making a particular contract that may exceed one year.

Table 1 presents our variables of interest according to the hypotheses highlighted in Section 2:

Table 1 - Potential Determinants of Number of Contracts in Basic Sanitation 


\begin{tabular}{|c|c|c|c|c|}
\hline Determinants & Hypothesis & Variables & Subtitles & $\begin{array}{c}\text { Data } \\
\text { Source }\end{array}$ \\
\hline \multirow[t]{2}{*}{$\begin{array}{l}\text { Foreign } \\
\text { Investment }\end{array}$} & $\begin{array}{l}\text { Hypothesis 1: Foreign capital investments } \\
\text { affect the number of infrastructure projects. }\end{array}$ & $\begin{array}{l}\text { Multilateral } \\
\text { debt (\% of } \\
\text { external debt) }\end{array}$ & multdebt & $\mathrm{WDI}^{[1]}$ \\
\hline & & $\begin{array}{l}\text { Direct foreign } \\
\text { investments } \\
(\% \text { of GDP) }\end{array}$ & invfor & WDI \\
\hline $\begin{array}{l}\text { Demand for } \\
\text { infrastruture }\end{array}$ & $\begin{array}{l}\text { Hypothesis 2: Developing countries that are } \\
\text { more populous demand more infrastructure } \\
\text { services, which encourages the formation of } \\
\text { partnerships with the private sector. }\end{array}$ & $\begin{array}{l}\text { Population } \\
\text { Growth }\end{array}$ & pop_growth & WDI \\
\hline $\begin{array}{l}\text { Macroeconomic } \\
\text { Environment }\end{array}$ & $\begin{array}{l}\text { Hypothesis 3: Private investments in } \\
\text { infrastructure are more likely in countries with } \\
\text { a stable macroeconomic environment }\end{array}$ & $\begin{array}{c}\text { Inflation } \\
\text { measured by } \\
\text { the PIB } \\
\text { deflator } \\
\text { Domestic } \\
\text { credit for the } \\
\text { private sector } \\
\text { (\% GDP) }\end{array}$ & $\begin{array}{l}\text { inf_gdp } \\
\text { credit_p }\end{array}$ & WDI \\
\hline $\begin{array}{c}\text { Business } \\
\text { Environment }\end{array}$ & $\begin{array}{c}\text { Hypothesis 4: A good business atmosphere } \\
\text { encourages private companies to get involved } \\
\text { in infrastructure projects. }\end{array}$ & $\begin{array}{c}\text { Economic } \\
\text { openness } \\
\text { [(Exports }+ \\
\text { Imports) } \\
\text { /GDP] }\end{array}$ & trade & WDI \\
\hline $\begin{array}{c}\text { Political } \\
\text { Environment }\end{array}$ & $\begin{array}{c}\text { Hypothesis 5: Politically stable economies are } \\
\text { more likely to attract investment through } \\
\text { private capital. }\end{array}$ & $\begin{array}{l}\text { Corruption } \\
\text { perception } \\
\quad \text { index }\end{array}$ & corrupt & $\begin{array}{l}\text { Governance } \\
\text { Indicators }\end{array}$ \\
\hline
\end{tabular}

Source: authors.

We have added year dummies to control possible economic shocks, such as the international crisis of 2008, which may have occurred in the period studied. We also added income (income, medium and low income) and region dummies, taking as base category the Latin America and the Caribbean region. Below we present the descriptive statistics of the variables used in our model.

\section{Table 2 - Descriptive Statistics}




\begin{tabular}{cccccc}
\hline Variables & Observations & Mean & Standard & Deviation & Mínimum \\
& & & & & Maximum \\
\hline project_n & 560 & 1.31 & 5.30 & 0 & 60 \\
\hline invfor & 560 & 4.28 & 4.91 & -0.51 & 50.02 \\
\hline inf_gdp & 560 & 7.06 & 7.63 & -29.69 & 80.75 \\
\hline multdebt & 560 & 21.63 & 18.33 & 0.02 & 87.82 \\
\hline trade & 553 & 77.08 & 36.06 & 19.10 & 210.37 \\
\hline pop_growth & 560 & 1.34 & 1.17 & -1.67 & 5.37 \\
\hline credit_p & 554 & 44.81 & 36.16 & 2.09 & 160.12 \\
\hline corrupt & 560 & -0.50 & 0.44 & -1.72 & 0.79 \\
\hline conc & 560 & 5 & 11.03 & 0 & 65 \\
\hline
\end{tabular}

Source: authors.

We can observe that there is an excessive number of zeros in our dependent variable. There are 408 observations where no new contract was signed in a given year in a country out of 560 observations. Next, we present how we constructed our control variable for the excess of zeros.

\subsubsection{Control Variable for the Excessive Number of Zeros}

When performing the regression with inflated models of zeros it is necessary to use a control variable for the excessive number of zeros of the sample. Since, when a country does not have the contract information in a given year, the dependent variable takes on zero value. In view of this, the excessive number of zeros can be explained by the fact that the concession contracts are long-term and, therefore, in the year in which the country does not have contract information in our sample, it may mean that it is complying with a current contract or renegotiating (MORAES and TAGLE, 2017). It is worth highlighting how many contracts of the database are in relation to the year in which it was signed.

Thus, based on the instrument used by Acemoglu et al. (2014), in which regional waves of democratization influence other countries to democratize, and may occur due to regional economic trends, causing a spillover effect (overflow). Thus, after the first democratization in a region, the participation of the countries that democratize in that region converges swiftly to other regions, which would be the waves of democratization. In this context, our hypothesis is that developing countries, from the same region, tend to follow concession practices in neighboring countries in order to leverage infrastructure investments, influencing the implementation of partnerships with the private sector, in order to fill the gap between fiscal restraint and demand for infrastructure.

In this way, we constructed a variable based on the number of contracts from neighboring countries in relation to the previous year for each country in our sample. Thus, to control the excessive number of zeros, we use a dummy variable that takes on the of value 1 when the neighboring country has a contract in the previous year, and 0 otherwise 
In addition, in order not to lose one year of the sample in the construction of the variable, we used the year 2002 that had information of contracts of the neighboring countries in the base of the PPI. Besides, in order not to lose a year of the sample in the construction of the variable, we used the year 2002 which possessed information of the contracts of the neighboring countries in the database of the PPI.

The following graphs show the number of contracts by region over the analyzed period and the percentage of the total number of contracts for each region. .

It can be observed that the East Asia and Pacific region holds the largest number of contracts in basic sanitation over the years, followed by Latin America and the Caribbean. We noticed a growth in the number of contracts in 2003 and a fall from 2007, which may have occurred due to the international crisis of 2008, affecting other regions as well, which can be explained by the fact that most of the investments in infrastructure are provided through foreign capital. In the next graph we describe the percentage of contracts by region in relation to the total contracts of the sector.

In graph 2 we present the percentage that each region holds of the total of analyzed contracts of the sector. The East Asia and Pacific region accounts for more than $50 \%$ of total contracts, with $58 \%$ of the region's $64 \%$ being contracts from China and $14 \%$ from $23 \%$ of the Latin American and Caribbean region belong to Brazil, characterizing these countries as the outliers of our sample. The next subsection describes the empirical strategy used in the estimates of this study.

\subsection{Empirical Strategy}

As an empirical strategy to perform the data estimates and to find the potential determinants of the number of contracts in infrastructure projects for the basic sanitation sector, we use counting estimators in the panel data structure. According to Wooldridge (2010), since the reason for a country's lack of data is not correlated with idiosyncratic errors, the unbalanced panel will not cause problems. Thus, in the absence of any observations, the panel used will be characterized as unbalanced.

Our model has a discrete count dependent variable, with the total number of contracts in water and sanitation. The default model for counting data is Poisson regression. However, because our data are overdispersed, with the variance greater than the mean in the dependent variable, the traditional Poisson regression model may have biased estimated parameters.

According to Cameron and Trivedi (2010), an alternative to treat overdispersion is to use the Poisson model with robust standard errors.

To solve the problem of the occurrence of a large number of zeros, we use the inflated regression models of zeros, introduced by Lambert (1992). When we analyzed the likelihood ratio test for the alpha parameter, we identified it to be the same statistically different from zero, rejecting the null hypothesis. Therefore, the Zero Inflated Negative Binomial model is preferable to the Poisson Zero Inflation model. In addition, to verify which model is most appropriate for our estimates, we performed the procedure 
proposed by Vuong (1989), in which the test statistic is normally distributed and compares the estimated models with and without zero inflation, in the case of Negative Binomial versus Zero Inflated Negative Binomial.

We interpret the result with positive and significant values indicating the adequacy of the Zero Inflated Negative Binomial model, and with negative and significant values indicating the adequacy of the traditional Negative Binomial model (FÁVERO and BELFIORE, 2017). When applied to our case, the $z$ value is significant for the Zero Inflated Negative Binomial (ZINB) model.

According to Desmarais and Harden (2013) the Vuong test is biased in deciding on the most appropriate model choice, always tending to the inflated zeros model, even when there is no overdispersion. Thus, the authors propose a correction to the Vuong test, which is based on the Akaike information criterion (AIC) and Bayesian (Schwarz) information criterion (BIC) statistics, and should therefore be performed to eliminate possible biases that may prejudice the decision with respect to choice of the most appropriate model. Therefore, we use Zero Inflated Negative Binomial with (Zero Inflated Negative Binomial with corrected Vuong (ZINBCV).

When performing the ZINBCV regression it is necessary to use a variable that can control the excessive number of zeros. In this way, we use the constructed variable based on the hypothesis that developing countries, from the same region, tend to follow concession practices of neighboring countries in order to leverage investments in infrastructure. Thus, we use a dummy variable that assumes value 1 when the neighboring country (which shares borders) had a contract in the previous year, and 0 otherwise, in relation to the previous year for each country in our sample.

While the inflated Poisson model of zeros is estimated from the combination of a Bernoulli distribution with a Poisson distribution, the inflated Negative Binomial zeros model is estimated by combining a Bernoulli distribution with a Poisson-Gamma distribution. Thus, one way to model counting data with overdispersion is to use the Binomial negative model. We follow Lambert (1992) and for Zero Inflated Negative Binomial model we have the following:

$$
P\left(Y_{i t}=y_{i t}\right)= \begin{cases}p_{i t}+\left(1-p_{i t}\right) \cdot\left(\frac{1}{1+\varnothing \lambda_{i t}}\right)^{\frac{1}{\phi}}, & y=0 \\ \left(1-p_{i t}\right) \cdot\left(\frac{y_{i t}+\phi^{-1}-1}{\phi^{-1}-1}\right) \cdot\left(\frac{\emptyset \lambda_{i t}}{1+\varnothing \lambda_{\text {it }}}\right)^{y_{i t}} \cdot\left(\frac{1}{1+\varnothing \lambda_{\text {it }}}\right), & y>0\end{cases}
$$

where yit is the number of contracts in basic sanitation $(y \geq 0)$, with a variation unit of $(i=1, \ldots, 40)$, that is, the countries, and $t$ indexes the time unit $(t=2003, \ldots, t=2016), \phi$, is the dispersion parameter, $p$ is the proportion of zeros, in which a probability exists, $p$, of the observation take on a value different to zero, that is $p(y i t \neq 0)$ and the possibility of the observation take on the zero value, $p(y i t=0)$, where: 


$$
\mathrm{p}_{\text {logit }}=\frac{1}{1+\exp \left(\gamma+\delta . \mathrm{W}_{\mathrm{it}}\right)}
$$

where $\mathrm{W}$ is the inflated variable that explains the zeros. In our model we used the control variable for concessions in neighboring countries for the idea of overflow effect: Finally, $\lambda$ it is defined as:

$$
\lambda_{\mathrm{it}}=\exp \left(\alpha+\beta_{1} \mathrm{X}_{1 \mathrm{t}}+\cdots+\beta_{\mathrm{k}} \mathrm{X}_{\mathrm{kt}}\right)
$$

where Xkt represents the potential determinants of the number of contracts for basic sanitation discussed previously.

Based on (1) and from the likelihood logarithm of the function (log likelihood) we can estimate $\phi, a, \beta 1$, $\ldots, \ldots k, y$ e $\delta 1$ of the Zero Inflation Negative Binomial Model (ZINB), and we have:

$$
\begin{gathered}
\mathrm{LL}=\sum_{\mathrm{Y}_{\mathrm{i}}=0} \ln \left[\mathrm{p}_{\mathrm{it}}+\left(1-\mathrm{p}_{\mathrm{it}}\right) \cdot\left(\frac{1}{1+\emptyset \lambda_{\mathrm{it}}}\right)^{\frac{1}{\phi}}\right]+ \\
\sum_{\mathrm{Y}_{\mathrm{i}}>0}\left[\ln \left(1-\mathrm{p}_{\mathrm{it}}\right)+\mathrm{Y}_{\mathrm{it}} \cdot \ln \left(\frac{\emptyset \lambda_{\mathrm{it}}}{1+\emptyset \lambda_{\mathrm{it}}}\right)-\frac{\ln \left(1+\emptyset \lambda_{\mathrm{it}}\right)}{\emptyset}\right] \\
\left.+\ln \Gamma\left(\mathrm{Y}_{\mathrm{it}}+\phi^{-1}\right)-\ln \Gamma\left(\mathrm{Y}_{\mathrm{it}}+1\right)-\ln \Gamma\left(\phi^{-1}\right)\right]=\max
\end{gathered}
$$

For the purpose of robustness analysis, we used the Negative and Poisson Binomial regression models with random effect, according to Hausman's test. In order to control heteroscedasticity, we used robust standard errors in all estimates. Thus, in order to capture the determinants of the number of private infrastructure investment contracts, we test as a dependent variable, the total number of projects, which account for the occurrence of private partnership agreements in the water and sanitation sector. In the next section we present the empirical results of the estimates made with the specified dependent variable.

\section{Empirical Results 5. Empirical Results}

In this section we discuss the empirical results with the Zero Inflation Negative Binomial with Vuong Correction model. As a robustness check, we estimate the Negative and Poisson Binomial models with random effects. We emphasize that all models present the same number of observations and the same variables of interest. 
In order to calculate the marginal effect, we used the method proposed by Beauhean and Morgan (2016), applying the following formula: $100 \times[\exp ($ estimated coefficient $\times \Delta)-1]$, where $\Delta$ is a change of a unit, $\Delta$ $=1$.

\subsection{Negative Zero Inflated Binomial Model}

In Table 3 we present the results for the Negative Binomial Inflated by Zeros model with Vuong's Correction (Zero-Inflated negative binomial with corrected Vuong - ZINBCV). We performed the Vuong (1989) test with correction, based on the AIC and BIC statistics, which compares the estimated model with and without zero inflation and, in this way. Results show ZINBCV model is adequate for our estimates. Each column in Table 3 presents a different specification, in order to capture the fixed effect of the temporal dummy, income dummy and region dummy, which has the Latin America and the Caribbean as base category.

For the ZINBCV regression, it is necessary to use a variable that controls for the excessive number of zeros. We use a dummy variable (conc) based on the idea that the influence of concession practices of neighboring countries (that share frontiers) generate an overflow effect, which indicates the probability of the existence of private investments in the country. Our control variable is statistically significant in all models with inflation of zeros.

Table 3 - Results for the Negative Inflation Zero Binomial Model 


\begin{tabular}{|c|c|c|c|c|}
\hline $\begin{array}{l}\text { Dependent variable: } \\
\text { number of contracts }\end{array}$ & ZINBCV & $\begin{array}{c}\text { ZINBCV } \\
\text { Dummy } \\
\text { Year }\end{array}$ & $\begin{array}{l}\text { ZINBCV } \\
\text { Dummy } \\
\text { Income }\end{array}$ & $\begin{array}{c}\text { ZINBCV } \\
\text { Dummy } \\
\text { Region }\end{array}$ \\
\hline \multirow[t]{2}{*}{ multdebt } & $-0.03^{* * *}$ & $-0.04^{* * *}$ & $-0.03^{* * *}$ & $-0.03^{* * *}$ \\
\hline & $(0.01)$ & $(0.01)$ & $(0.01)$ & $(0.01)$ \\
\hline \multirow[t]{2}{*}{ invfor } & -0.01 & 0.02 & -0.00 & $0.05^{*}$ \\
\hline & $(0.03)$ & $(0.03)$ & $(0.03)$ & $(0.03)$ \\
\hline \multirow[t]{2}{*}{ pop_growth } & $-0.23^{* *}$ & -0.09 & $-0.20^{*}$ & -0.32 \\
\hline & $(0.10)$ & $(0.09)$ & $(0.11)$ & $(0.22)$ \\
\hline \multirow[t]{2}{*}{ inf_gdp } & -0.00 & $-0.03^{*}$ & -0.00 & 0.00 \\
\hline & $(0.02)$ & $(0.01)$ & $(0.02)$ & $(0.01)$ \\
\hline \multirow[t]{2}{*}{ credit_p } & $0.02^{* * *}$ & $0.03^{* * *}$ & $0.02^{* * *}$ & 0.00 \\
\hline & $(0.00)$ & $(0.00)$ & $(0.00)$ & $(0.00)$ \\
\hline \multirow[t]{2}{*}{ trade } & $-0.02^{* * *}$ & $-0.03^{* * *}$ & $-0.02^{* * *}$ & $-0.03^{* * *}$ \\
\hline & $(0.00)$ & $(0.00)$ & $(0.00)$ & $(0.00)$ \\
\hline \multirow[t]{2}{*}{ corrupt } & 0.32 & 0.11 & -0.11 & $0.69^{* *}$ \\
\hline & $(0.28)$ & $(0.23)$ & $(0.28)$ & $(0.33)$ \\
\hline Temporal dummies & no & yes & no & no \\
\hline \multirow[t]{2}{*}{ drenda } & & & $-0.92^{* * *}$ & \\
\hline & & & $(0.19)$ & \\
\hline \multirow[t]{2}{*}{ dAFR } & & & & $-0.82^{*}$ \\
\hline & & & & $(0.42)$ \\
\hline \multirow[t]{2}{*}{ dLAP } & & & & $2.04^{* * *}$ \\
\hline & & & & $(0.43)$ \\
\hline \multirow[t]{2}{*}{$\mathrm{dEAC}$} & & & & -0.55 \\
\hline & & & & $(0.58)$ \\
\hline \multirow[t]{2}{*}{ dOMNA } & & & & -0.00 \\
\hline & & & & $(0.40)$ \\
\hline \multirow[t]{2}{*}{ dSA } & & & & -0.22 \\
\hline & & & & $(0.39)$ \\
\hline \multicolumn{5}{|l|}{ inflate } \\
\hline \multirow[t]{2}{*}{ conc } & $-1.48^{* *}$ & $-1.80^{*}$ & $-1.21^{* * *}$ & $-12.42^{* * *}$ \\
\hline & $(0.60)$ & $(0.98)$ & $(0.40)$ & $(1.93)$ \\
\hline \multirow{3}{*}{$\begin{array}{l}\text { Vuong Test Binomial Negative versus } \\
\text { ZINB: }\end{array}$} & $\mathrm{z}=2.29$ & $\mathrm{z}=2.23$ & $\mathrm{z}=2.52$ & $\mathrm{z}=1.25$ \\
\hline & $\operatorname{Pr}>\mathrm{z}=$ & $\operatorname{Pr}>\mathrm{z}=$ & $\operatorname{Pr}>\mathrm{z}=$ & $\operatorname{Pr}>\mathrm{z}=$ \\
\hline & 0.0110 & 0.0129 & 0.0058 & 0.1050 \\
\hline \multirow[t]{2}{*}{ Correction with AIC (Akaike): } & $z=1.89$ & $z=1.89$ & $\mathrm{z}=2.14$ & $\mathrm{z}=0.52$ \\
\hline & $\begin{array}{l}\operatorname{Pr}>z= \\
0.0296\end{array}$ & $\begin{array}{l}\operatorname{Pr}>z= \\
0.0293\end{array}$ & $\begin{array}{l}\operatorname{Pr}>z= \\
0.0162\end{array}$ & $\begin{array}{l}\operatorname{Pr}>z= \\
0.2999\end{array}$ \\
\hline Correction with BIC (Schwarz): & $z=1.02$ & $\mathrm{z}=1.16$ & $\mathrm{z}=1.32$ & $z=-1.04$ \\
\hline
\end{tabular}




\begin{tabular}{ccccc} 
& $\operatorname{Pr}>\mathrm{z}=$ & $\operatorname{Pr}>\mathrm{z}=$ & $\operatorname{Pr}>\mathrm{z}=$ & $\operatorname{Pr}<\mathrm{z}=$ \\
& 0.1548 & 0.1226 & 0.0941 & 0.1482 \\
\hline № Observations & $\mathbf{5 4 7}$ & $\mathbf{5 4 7}$ & $\mathbf{5 4 7}$ & $\mathbf{5 4 7}$ \\
\hline
\end{tabular}

Source: authors.

Notes: Robust Standard errors between parentheses * significant at $10 \% * *$ significant at $5 \%$ and significant $* * *$ at 1\%. The regions are described as: Africa - AFR; East Asia and the Pacific - EAP; Europe and Central Asia ECA; Latin America and the Caribbean - LAC; Middle East and North Africa - MENA and South Asia - SA.

Obs.: Classification of the regions from the World Bank.

Our results show that the multilateral debt (multdebt) as a percentage of the external debt stock has a negative impact on all models with zero inflation (ZINBCV), which means that on average an increase of $1 \%$ in multilateral debt would lead to a $3.92 \%$ reduction in the number of contracts. This indicates that the fulfillment of the commitments with the country creditors is an important factor to explain the growth of the number of contracts. On the other hand, external indebtedness may soften the restraint of financial resources for infrastructure investments and, alternatively, could mean that government authorities may capture external resources more easily. Results also indicate a 1\% increase in direct foreign investment as a percentage of GDP generates an increase of $5.13 \%$ in the number of contracts, allowing the formation of new contracts and reinforcing the hypothesis that investments through foreign capital influence the number of contracts.

As for demand for infrastructure, we see a negative impact, in which a $1 \%$ increase in population growth (pop_growth) reduces demand for projects by approximately $20.55 \%$. In the macroeconomic environment, inflation (inf_gdp) has a negative impact, in which the $1 \%$ increase leads to a reduction of $2.96 \%$ in the number of contracts. On the other hand, the domestic credit to the private sector (credit_p) has a positive effect on all estimates, except when we include a region dummy, where a $1 \%$ increase in private credit generates an increase of $3.05 \%$ in the number of contracts. This indicated that the incentives for private capital inflows into the economy are an important factor in the formulation of contracts for the water and sanitation sector. In this way, developing countries with stable macroeconomic conditions are more likely to attract private capital to leverage the number of infrastructure contracts in the sector, since the initial investment is high and the return is long term.

As for the business environment, we can see that the economic openness (trade) has a negative impact on all models, in which a $1 \%$ increase in economic openness reduces the number of contracts by $2.96 \%$. In relation to the corruption index (corrupt), results indicate that countries with political stability motivate investors to engage in infrastructure projects. It should be noted that the corruption index is a perception of how the country is viewed internationally by other nations, capturing how public power is exercised for private gain.

Our income dummy is statistically significant and negative, that is, the fact that the nation is middleincome within the set of emerging countries entails a reduction of approximately $60 \%$ in the number of contracts. The region of Africa has a negative effect of approximately $55 \%$, possibly because this region is less developed economically relative to the Latin America and the Caribbean region. The positive result 
for the East Asia and Pacific region may be explained by the presence of China, which holds more than $50 \%$ of the contracts of our sample.

We highlight the results of our control variable for the excessive number of zeros, assuming that developing countries, in the same region, tend to follow concession practices in neighboring countries, in which there is a spillover effect. We emphasize that the coefficient of the inflated variable explains the probability of always have zero contracts. In the dummy income model, the fact that neighboring countries have contracts in basic sanitation reduces in approximately $70 \%$ the probability of countries that share frontiers not having contracts in the sector indicating an overflow effect. In other words, the fact that countries that share frontiers with Brazil, for instance, have concession practices, reduces the country's probability of not having contracts in the sanitation sector. In this way, the foreign investment, the macroeconomic condition and the political stability are important channels for the formulation of contracts for the water and sanitation sector.

\section{2 - Negative and Poisson Binomial Models}

Compared with the results for the inflated zeros (ZINBCV) model, Table 4 shows that the signs of the coefficients of domestic credit to the private sector (credit_p) and economic opening (trade) in the Negative Binomial and Poisson models are opposite, since we are not controlling for the excess of zeros in our dependent variable. The demand for infrastructure, with population growth (pop_growth), maintains the negative and significant effect relationship with the number of contracts. We also observe that the foreign investment channel (multdebt) and (invfor) and the political environment channel (corrupt) facilitate the formulation of new contracts.

\section{Table 4 - Total Number of Projects with Negative and Poisson Binomial Models}




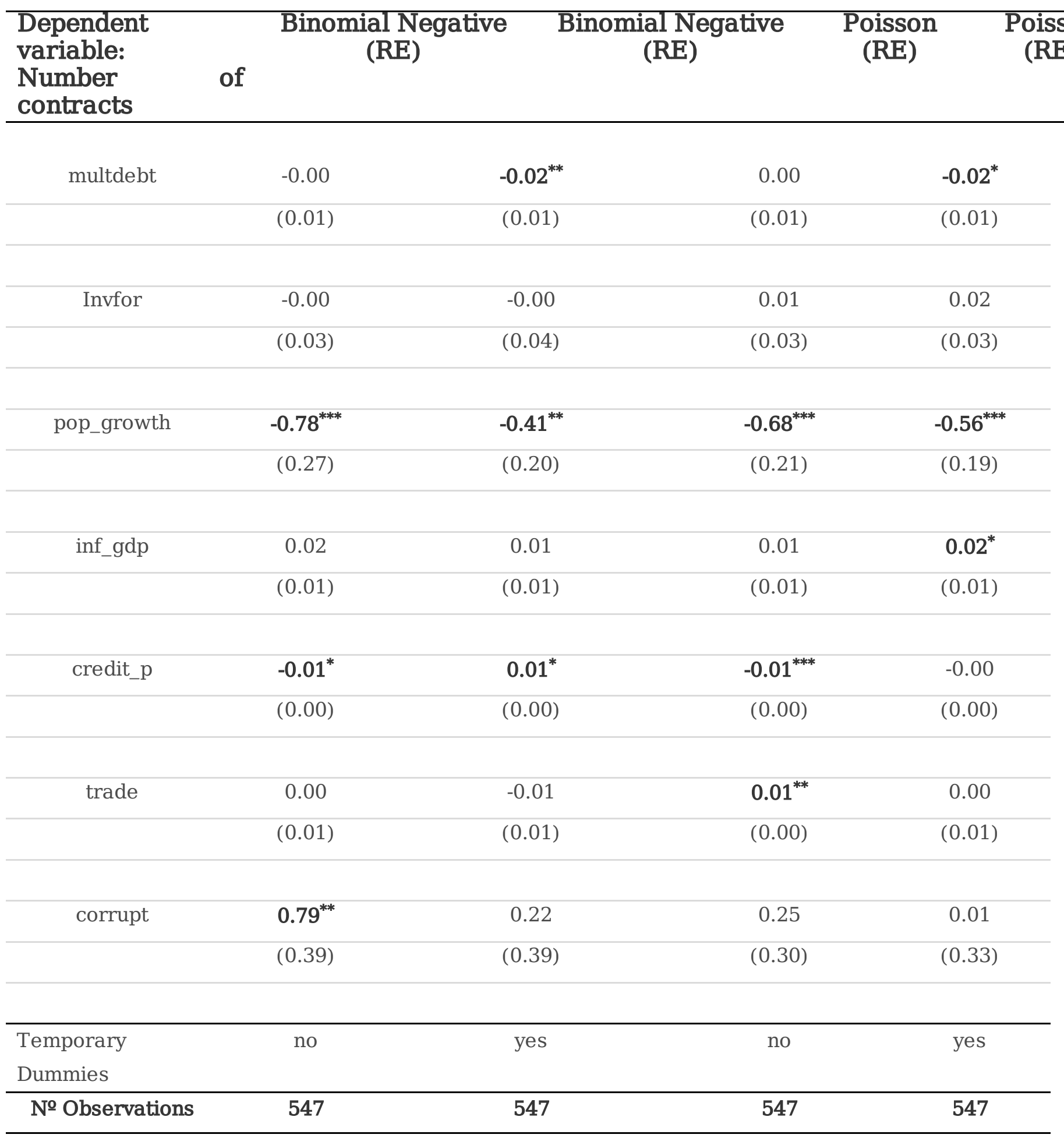

Source: authors.

Notes: The result tables display Binomial Negative and Poisson side by side for comparison purposes.

Robust Standard errors between parentheses * significant at 10\%** significant at 5\% and significant *** at 1\%.

Our results are aligned with Yehoue et al. (2006), this presents evidence that the channels of budgetary restraint, macroeconomic environment, rule of law and demand for infrastructure are determinant for 
private investment. In this study, we observed that foreign direct investment and political stability also stand out as important channels for increasing the number of contracts in the basic sanitation sector.

In the study of Sharma (2012), political stability and market size are important determinants of infrastructure projects. Differently, in our analysis, we report that the foreign investment channel and a stable macroeconomic environment stand out as channels for the number of contracts in the sector, given that most investments are financed with foreign capital and a sound macroeconomic environment is important to reduce uncertainties for the private companies.

Overall, our estimates are in agreement with previous studies. However, our results suggest that the foreign investment channel is an important determinant of the increase in the number of contracts in basic sanitation sector.

In the models used for the robustness analysis, even if some coefficients were kept with the same signals of the zero inflation model, other coefficients presented opposite signs, which may be due to the fact that we are not controlling the excessive number of zeros, reinforcing the results found in the ZINB model. In this way, the Zero Inflation Negative Binomial model presents more robust and consistent results, justifying the significance of the control variable used for zero inflation.

In short, a stable macroeconomic environment, investment through foreign capital and political stability contribute to the increase in the number of contracts in the basic sanitation sector. We emphasize that our control variable for the excessive number of zeros has a strong overflow effect in all the estimated models, in which it reduces the probability that neighboring countries (that share borders) do not have contracts in the water and sanitation sector.

\section{Final Considerations}

Access to basic sanitation is an essential factor for the sustainable development of countries. Inefficiency in the infrastructure sector directly affects public health and the quality of life of individuals. Therefore, in order to solve bottlenecks in infrastructure to meet growing demands, the participation of private investors in infrastructure projects has been debated among governmental authorities, as changes in the relationship between public and private sector may be used to achieve greater efficiency in the provision of services and to increase social welfare.

Following Yehoue et al. (2006) and Sharma (2012), this study investigated the determinants of the number of contracts for the basic sanitation sector in developing countries, from 2003 to 2016 . Our study contributes to the literature in two ways: (i) we consider the effect of foreign investment; and (ii) we add a specific variable to control for the excessive number of zeros in our dependent variable.

The zero control variable is based on the premise that the concessionary practices of countries in the same region, that is, that have common frontiers, generate a spillover effect for neighboring countries to adhere to this arrangement. The results show a strong overflow effect in all the estimated models, in 
which it reduces the probability of neighboring countries not having contracts in the water and sanitation sector.

Relative to the potential determinants of private investment, political stability is fundamental to strengthen institutions and provide a good business environment for foreign investment. In the same way, a stable macroeconomic environment can reduce the uncertainty in the choice of the private enterprises for the investment in infrastructure projects, thus being the predominant determinants for the increase in the number of contracts in the basic sanitation sector.

In short, partnerships between the public and private sectors, through concession contracts, may assist public policymakers as an instrument in addressing bottlenecks in the basic sanitation sector, meeting growing demands, bringing innovation and technology to the sector.

\section{Declarations}

\section{Availability of data and material}

The datasets generated and/or analysed during the current study are available in the The World Bank, repositor on the link: https://ppi.worldbank.org/en/ppidata and World Bank, repositor on the link: https://databank.worldbank.org.

\section{Competing interests}

Not applicable for that section.

\section{Funding}

Not applicable for that section.

\section{Authors' contributions}

Not applicable for that section.

\section{Acknowledgements}

Not applicable for that section.

\section{Authors' information (optional)}

Not applicable for that section. 


\section{References}

1. ACEMOGLU, D.; ROBINSON, J. The role of institutions in growth and development. Leadership and Growth, (10):135, 2008.

2. ACEMOGLU, Daron et al. Democracy does cause growth. National Bureau of Economic Research, 2014.

3. BEAUJEAN, A. Alexander; MORGAN, Grant B. Tutorial on Using Regression Models with Count Outcomes using R. Practical Assessment, Research \& Evaluation, v. 21, 2016.

4. BENNETT, John; IOSSA, Elisabetta. Building and managing facilities for public services. Journal of public economics, v. 90, n. 10-11, p. 2143-2160, 2006.

5. CAMERON, Adrian Colin; TRIVEDI, Pravin K. Microeconometrics using stata. College Station, TX: Stata press, 2010.

6. CAMERON, Colin; TRIVEDI, Pravin. Models for count data. 1998.

7. CHONG, Eshien et al. Public-private partnerships and prices: evidence from water distribution in France. Review of Industrial Organization, v. 29, n. 1-2, p. 149, 2006.

8. DE GREGORIO, José et al. Economic growth in Latin America: sources and prospects. 1999.

9. DESMARAIS, Bruce A. et al. Testing for zero inflation in count models: Bias correction for the Vuong test. The Stata Journal, v. 13, n. 4, p. 810-835, 2013.

10. ENGEL, Eduardo; FISCHER, Ronald; GALETOVIC, Alexander. Soft budgets and renegotiations in public-private partnerships. National Bureau of Economic Research, 2009.

11. ESTACHE, A. Infrastructure: a survey of recent and upcoming issues. the World Bank infrastructure vice-presidency, and poverty reduction and economic management vice-presidency.

12. FAVERO, Luiz; FAVERO, Patricia. Manual de análise de dados: estatística e modelagem multivariada com Excel®, SPSS $\AA^{8}$ e Stata ${ }^{\circledR}$. Elsevier Brasil, 2017.

13. FERNANDEZ, Rodrigo Nobre et al. Impacto dos determinantes das parcerias público privadas em economias emergentes. Planejamento e Políticas Públicas, n. 44, 2015.

14. FERNANDEZ, Rodrigo Nobre et al. Uma abordagem de Law \& Economics para as Parcerias PúblicoPrivadas no Brasil DOI: http://dx. doi. org/10.18836/2178-0587/ealr. v5n2p205-219. Economic Analysis of Law Review, v. 5, n. 2, p. 205-219, 2015.

15. FERREIRA, Pedro Cavalcanti; FRANÇA, J. M. S. Um estudo sobre infra-estrutura: impactos produtivos, cooperação público-privado e desempenho recente na América Latina. Documento não publicado, 
2007.

16. FUJIWARA, Thomas et al. A privatização beneficia os pobres? Os efeitos da desestatização do saneamento básico na mortalidade infantil. Anais do XXXIII Encontro Nacional de Economia, 2005.

17. FRONE, Simona et al. Public-Private Partnerships as Mechanisms for Risk Management in the Water Sector. SCIENTIFIC PAPERS, p. 103, 2013.

18. GUASCH, J. Luis. Granting and renegotiating infrastructure concessions: doing it right. World Bank Publications, 2004.

19. HARRIS, Clive. Private participation in infrastructure in developing countries: trends, impacts, and policy lessons. World Bank Publications, 2003.

20. HART, Oliver. Incomplete contracts and public ownership: Remarks, and an application to publicprivate partnerships. The Economic Journal, v. 113, n. 486, 2003.

21. HART, Oliver; SHLEIFER, Andrei; VISHNY, Robert W. The proper scope of government: theory and an application to prisons. The Quarterly Journal of Economics, v. 112, n. 4, p. 1127-1161, 1997.

22. IOSSA, Elisabetta; MARTIMORT, David. Risk allocation and the costs and benefits of public--private partnerships. The RAND Journal of Economics, v. 43, n. 3, p. 442-474, 2012.

23. IOSSA, Elisabetta; SAUSSIER, Stephane. Public Private Partnerships In Europe For Building And Managing Public Infrastructures: An Economic Perspective. Annals of Public and Cooperative Economics, v. 89, n. 1, p. 25-48, 2018

24. JIANG, Yi et al. Privatization, governance, and survival: MNE investments in private participation projects in emerging economies. Journal of World Business, v. 50, n. 2, p. 294-301, 2015.

25. KISHIMOTO, Satoko; PETITJEAN, Olivier. Reclaiming Public Services: How Cities and Citizens are Turning Back Privatisation. Amsterdã e Paris: Transnational Institute, 2017.

26. LAMBERT, Diane. Zero-inflated Poisson regression, with an application to defects in manufacturing. Technometrics, v. 34, n. 1, p. 1-14, 1992.

27. NISAR, Tahir M. Risk management in public-private partnership contracts. Public Organization Review, v. 7, n. 1, p. 1-19, 2007.

28. PISTOR, Katharina; RAISER, Martin; GELFER, Stanislaw. Law and finance in transition economies. Economics of transition, v. 8, n. 2, p. 325-368, 2000.

29. PRASAD, Naren. Privatisation results: Private sector participation in water services after 15 years. Development Policy Review, v. 24, n. 6, p. 669-692, 2006. 
30. PUSOK, Krisztina. Public-Private Partnerships and Corruption in the Water and Sanitation Sectors in Developing Countries. Political Research Quarterly, v. 69, n. 4, p. 678-691, 2016.

31. RESIDE, Jr Renato E. Global determinants of stress and risk in public-private partnerships (PPP) in infrastructure. 2009.

32. SHARMA, Chandan. Determinants of PPP in infrastructure in developing economies. Transforming Government: People, Process and Policy, v. 6, n. 2, p. 149-166, 2012.

33. SIQUEIRA MORAES, Marcos; REYES-TAGLE, Gerardo. Os impactos fiscais dos contratos de parceria público-privada: Estudo de caso do ambiente institucional e da prática no Brasil. Inter-American Development Bank, 2017.

34. THOMSEN, Stephen. Encouraging public-private partnerships in the utilities sector: the role of development assistance. Investment for African Development: Making it Happen, p. 25-27, 2005.

35. TRUJILLO, Lourdes et al. Macroeconomic effects of private sector participation in Latin America's infrastructure. World Bank Publications, 2002.

36. TULLOCK, Gordon; ROWLEY, Charles Kershaw. The rent-seeking society. Liberty Fund Inc., 2005.

37. VEDACHALAM, Sridhar; GEDDES, R. Richard; RIHA, Susan J. Public-private partnerships and contract choice in India's water and wastewater sectors. Public Works Management \& Policy, v. 21, n. 1, p. 71-96, 2016.

38. VUONG, Quang H. Likelihood ratio tests for model selection and non-nested hypotheses. Econometrics: Journal of the Econometric Society, p. 307-333, 1989.

39. WANG, Hongwei; WU, Wenqing; ZHENG, Shilin. An econometric analysis of private sector participation in China's urban water supply. Utilities Policy, v. 19, n. 3, p. 134-141, 2011.

40. WOOLDRIDGE, Jeffrey M. Econometric analysis of cross section and panel data. MIT press, 2010.

41. WORLD HEALTH ORGANIZATION et al. Investing in water and sanitation: increasing access, reducing inequalities: GLAAS 2014 findings-highlights for the Eastern Mediterranean Region. World Health Organization, 2015.

42. YANG, Zhao et al. Testing approaches for overdispersion in Poisson regression versus the generalized Poisson model. Biometrical journal, v. 49, n. 4, p. 565-584, 2007.

43. YEHOUE, Mr. Etienne B.; HAMMAMI, Mona; RUHASHYANKIKO, Jean-François. Determinants of publicprivate partnerships in infrastructure. International Monetary Fund, 2006.

44. ZENELI, Fjona. Between Public-Private Partnerships and public finance in the public infrastructure sector\&58; The water and sanitation sector in Albania. Academic Journal of Business, v. 3, n. 1, p. 
205-212, 2017.

Figures

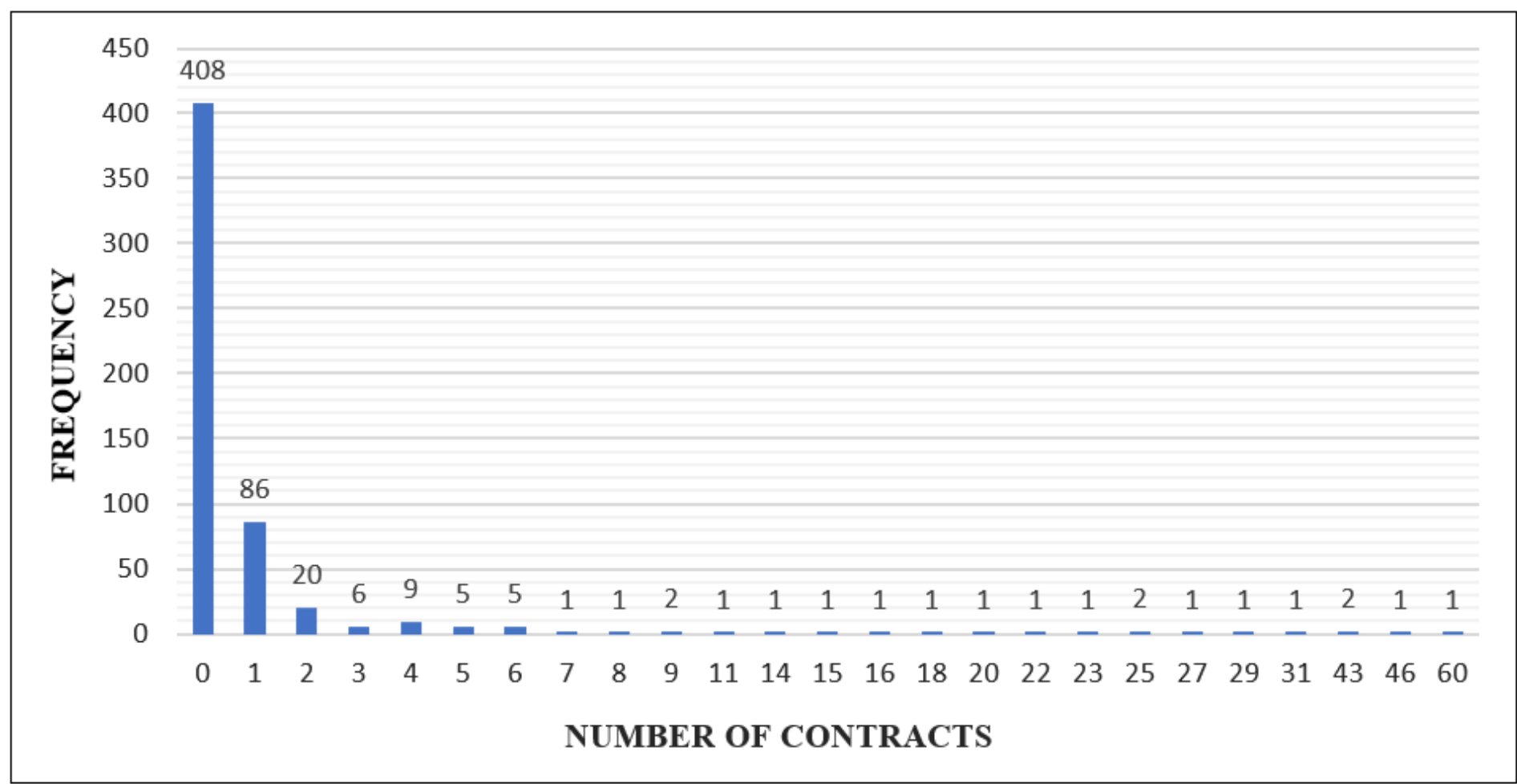

Source: authors.

Figure 1

Graph 1: Frequency Distribution for the Number of Contracts 


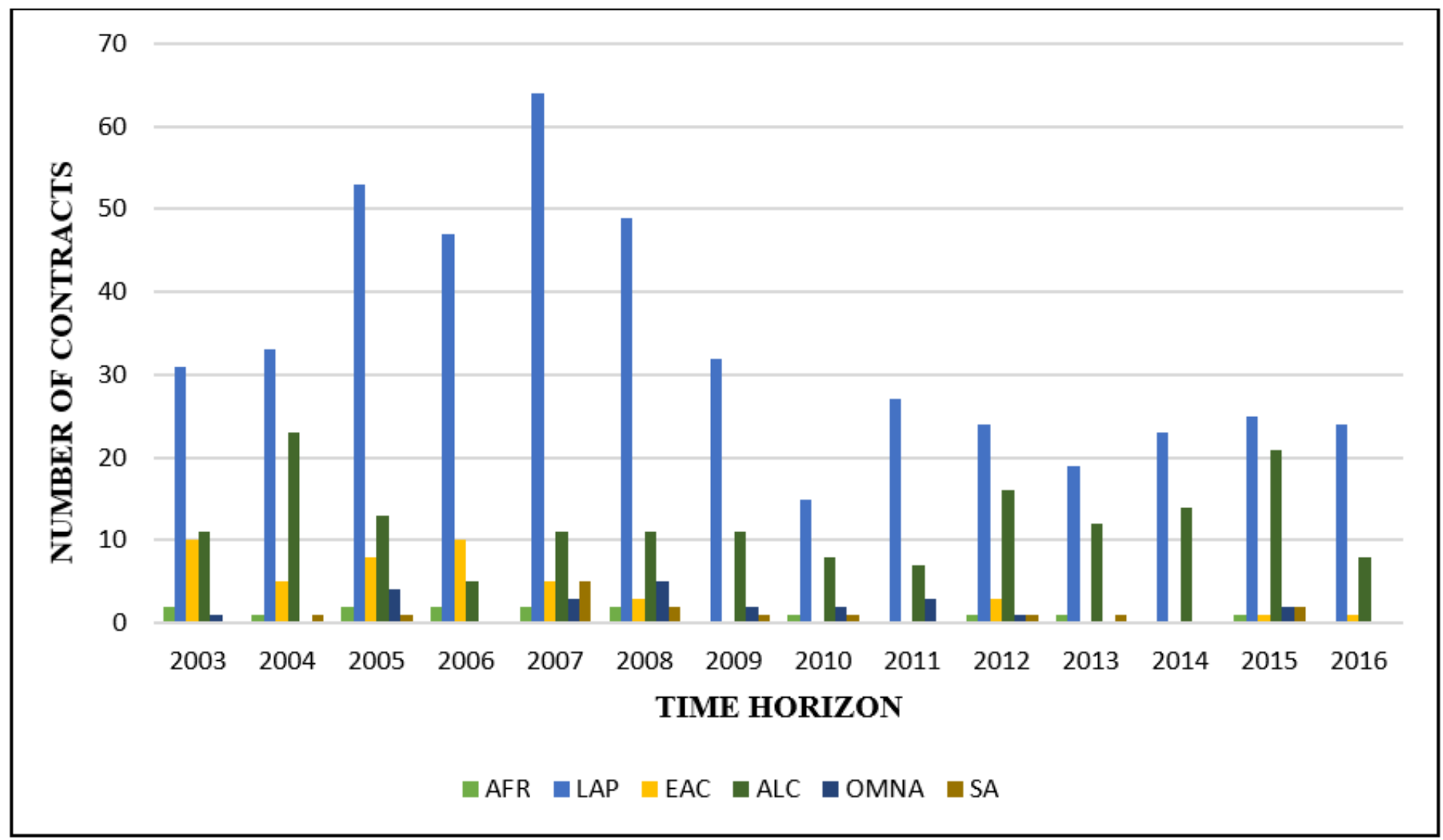

Source: authors.

Note: Regions are described as: Africa - AFR; East Asia and the Pacific - EAP; Europe and Central Asia - ECA; Latin America and the Caribbean - LAC; Middle East and North Africa - MENA and South Asia - SA. Note: Classification of regions by the World Bank.

Figure 2

Graph 2: Number of Contracts per Region 


\section{Total of Contracts}

\section{6}

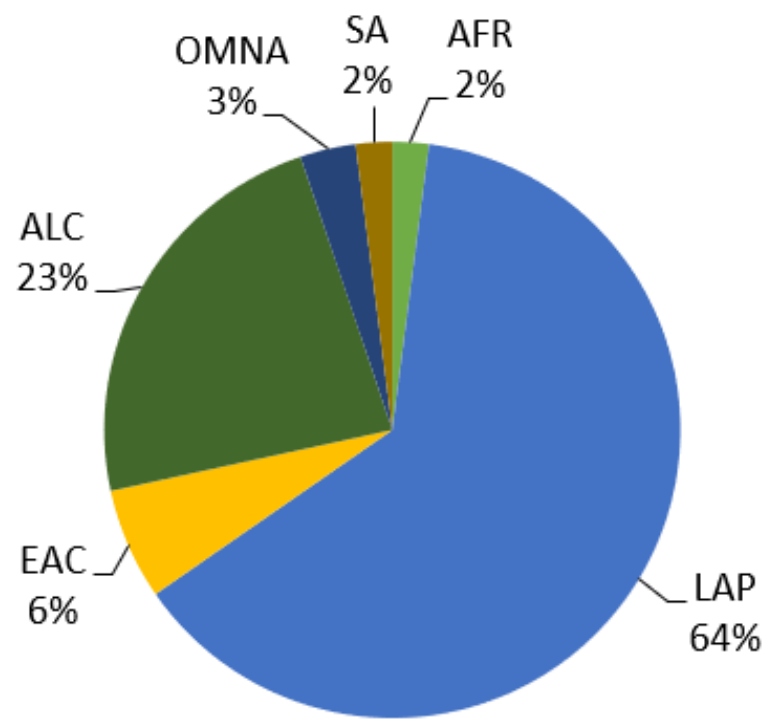

$\square$ AFR $\square$ LAP $\square$ EAC $\square$ ALC $\square$ OMNA $\square$ SA

Source: authors.

Note: The regions are described as: Africa - AFR; East Asia and the Pacific - EAP; Europe and Central Asia ECA; Latin America and the Caribbean - LAC; Middle East and North Africa - MENA and South Asia - SA.

Obs.: Classification of regions by the World Bank.

\section{Figure 3}

Graph 3: Percentage of Contracts per Region

\section{Supplementary Files}

This is a list of supplementary files associated with this preprint. Click to download.

- Appendix.docx 